\title{
Albumin Gene Expression Is Down-regulated by Albumin or Macromolecule Infusion in the Rat
}

\author{
Antonello Pietrangelo, Arturo Panduro, Jayanta Roy Chowdhury, and David A. Shafritz \\ Marion Bessin Liver Research Center and the Departments of Medicine and Cell Biology, Albert Einstein College of Medicine, \\ Bronx, New York 10461
}

\begin{abstract}
A novel feedback regulatory mechanism operating on transcription of the albumin gene is described in the rat. In 1946, it was proposed that circulating colloids, including serum albumin, may affect the synthesis and/or secretion of albumin in the liver. The molecular basis for this proposed regulation has now been investigated by adding oncotically active macromolecules to the circulation of normal or genetically albumin-deficient Nagase analbuminemic rats (NAR) and analyzing the hepatic expression of genes, including albumin after $24 \mathrm{~h}$. The transcription rate of the albumin gene was higher in NAR than in normal rats and was dramatically reduced by raising serum albumin to $1.6 \mathrm{~g} / \mathrm{dl}$. Intravenous infusion of albumin into normal rats also decreased transcriptional activity of the albumin gene by $50-60 \%$, and this decrease correlated with changes in serum colloid osmotic pressure after albumin infusion. Inhibition of albumin gene transcription was also observed upon intravenous infusion of other protein or nonprotein macromolecules, such as $\boldsymbol{\gamma}$-globulin and dextran. This down-regulation appears to control the steady-state level of albumin mRNA in the liver. Aside from a concomitant decrease in apo $\mathbf{E}$ gene transcription after albumin or macromolecule infusion, there was no change in the transcription rate of other genes, including those exhibiting liver-preferred or -specific expression (e.g., tyrosine aminotransferase, cytochrome P-450, $\alpha_{1}$-antitrypsin, apolipoproteins $A-I$ and $B$, and transferrin) or general cellular expression (e.g., $\alpha$-tubulin, pro $\alpha_{2}$ collagen, and $\beta$-actin). Feedback regulation of albumin gene expression by serum colloids may serve as a specific homeostatic mechanism to maintain the steady-state level of total protein in the circulation. (J. Clin. Invest. 1992. 89:1755-1760.) Key words: feedback control • serum colloids • transcriptional regulation • colloid osmotic pressure • plasma proteins
\end{abstract}

This work was presented in part at the Annual Meeting of the American Federation for Clinical Research/American Society of Clinical Investigation/Association of American Physicians in Seattle, WA, May 1991. Portions of this work have appeared in abstract form (1991. Clin. Res. 39:302a).

Address reprint requests to D. A. Shafritz, M.D., Liver Research Center, Albert Einstein College of Medicine, 1300 Morris Park Avenue, Bronx, NY 10461.

Received for publication 21 June 1991 and in revised form $27 \mathrm{No}$ vember 1991.

J. Clin. Invest.

(c) The American Society for Clinical Investigation, Inc.

0021-9738/92/06/1755/06 \$2.00

Volume 89, June 1992, 1755-1760

\section{Introduction}

The liver represents the main source of serum albumin $(1,2)$. Normally, the plasma albumin concentration remains constant at 3.5-4.0 g/dl, suggesting an active regulation of albumin metabolism. Several pathophysiological studies have shown that hormones, malnutrition, and stress may influence albumin synthesis (3-7); however, little is known about the "physiological" regulator(s) of albumin or other proteins synthesized by the liver. Many years ago, Biorneboe $(8,9)$ observed that an increase in the serum concentration of globulins is followed by a concomitant decrease of serum albumin in hepatitis and after immunization, and he proposed that the serum colloid osmotic pressure (COP) ${ }^{1}$ might serve as a regulator for changes in serum protein concentration. In support of this hypothesis, hyperglobulinemia, infusion of $\gamma$-globulin, and administration of dextran were also shown to decrease serum albumin levels (1012). Moreover, in a variety of conditions in which serum albumin levels fall either acutely (e.g., plasmapheresis) or chronically (e.g., nephrotic syndrome), hepatic albumin synthesis is increased (13-15).

In the 1960's, Rothschild et al. (16) demonstrated that addition of albumin to the perfusate medium of the isolated rabbit liver decreases incorporation of labeled amino acids into albumin. Other studies extended this observation to macromolecules other than albumin, and it was proposed that all these agents may work through a common feedback mechanism based on their ability to influence the $\operatorname{COP}(17,18)$. However, the molecular basis for this regulation has never been identified, and at present it is not known whether the proposed feedback regulation operates on albumin synthesis at the transcriptional, posttranscriptional, or translational level or on albumin secretion.

To test the hypothesis that serum colloids may affect the synthesis of albumin in the intact liver, we added oncotically active macromolecules to the circulation of normal SpragueDawley rats (SDR) or Nagase analbuminemic rats (NAR) and used a molecular approach to analyze expression of the albumin gene. Since NAR have virtually no albumin in the serum (19), and low serum COP (20), analyses in both NAR and normal SDR would be useful in testing different aspects of albumin gene expression and its regulation in response to external manipulations. Expression of other specific genes, including those coding for unique liver functions, functions

1. Abbreviations used in this paper: $\alpha_{1}$-AGP, $\alpha_{1}$-acid glycoprotein; $\alpha_{1}$ AT, $\alpha_{1}$-antitrypsin; $\alpha_{2}$-coll, pro- $\alpha_{2}$ (I)-collagen; Alb, albumin; COP, colloid osmotic pressure; NAR, Nagase analbuminemic rats; SDR, SpragueDawley rats; TAT, tyrosine aminotransferase; Tf, transferrin; UDPGT, androsterone-uridine diphosphoglucuronyl transferase. 
enriched in the liver but not unique, and common cellular or "housekeeping" functions, was also analyzed to determine the extent to which expression of these genes is influenced in vivo by albumin or other macromolecule infusion.

\section{Methods}

Male SDR and NAR (180-200 $\mathrm{g}$ body wt) received, under ether anesthesia, a single transjugular injection of $3.5-4 \mathrm{mg} / \mathrm{g}$ body wt of rat serum albumin, dextran (mol wt $\sim 70 \mathrm{kD}$ ), or rat gamma-globulins (Sigma Chemical Co., St. Louis, MO) dissolved in 1-2 ml of saline. Control rats received 1-2 $\mathrm{ml}$ of saline alone under the same conditions. All solutions were passed through a bacterial filter (pore size $0.20 \mu \mathrm{m}$; RFS, Dublin, CA) before injection. After 20-24 h, rats were killed by cardiac puncture under light ether anesthesia. Livers were removed quickly and perfused at $4^{\circ} \mathrm{C}$ with $50 \mathrm{ml}$ of a solution containing $0.25 \mathrm{M}$ sucrose, $1 \mathrm{mM} \mathrm{MgCl}$, and $10 \mathrm{U} / \mathrm{ml}$ heparin. An aliquot of tissue was frozen in liquid nitrogen and stored at $-80^{\circ} \mathrm{C}$ until RNA extraction and RNA blot analysis. The remaining tissue was used for isolation of nuclei.

In vitro transcription in isolated nuclei ("run-on" assay). Nuclei were isolated by centrifugation through a sucrose gradient as previously described (21); however, the protocol for measuring the relative transcription rates of hepatic genes was modified slightly. Briefly, after isolating and labeling $20-40 \times 10^{6}$ nuclei in vitro with $30 \mu \mathrm{Ci}$ of uridine $\left[\alpha^{32} \mathrm{P}\right]$ triphosphate (sp act $410 \mathrm{Ci} / \mathrm{mmol}$; Amersham, Searle Corp., Arlington Heights, IL) as previously reported (21), labeled RNA was isolated by SDS-proteinase $\mathrm{K}$ digestion, followed by phenol-chloroform extraction and ethanol precipitation. The relative transcription rate of a large number of hepatic genes was then analyzed simultaneously in a given RNA extract by filter hybridization, using a series of cloned DNAs ( $5 \mu \mathrm{g}$ each) applied as slots to nitrocellulose filter sheets (pore size $0.45 \mu \mathrm{m}$; Schleicher \& Schuell Inc., Keene, $\mathrm{NH}$ ), according to the method of Clayton and Darnell (22). The following cDNA clones, kindly provided by the individuals noted, were used: rat albumin (Alb) (D. A. Shafritz); rat $\alpha$-fetoprotein (T. Sargent); apo E, A-I, and A-II (L. Chan) and apo B (A. J. Lusis); $\beta$-fibrinogen (G. R. Crabtree); $\alpha_{1}$-antitrypsin $\left(\alpha_{1}-\mathrm{AT}\right)$ (K. Krauter); ligandin and $\alpha_{1}$-acid glycoprotein ( $\alpha_{1}$-AGP) (J. Taylor), transferrin (Tf) (J. Griswold); $\alpha$-tubulin, $\beta$-actin, and 28-S rDNA (L. Reid and D. Clayton); pro- $\alpha_{2}(\mathrm{I})$-collagen $\left(\alpha_{2}\right.$-coll)(D. Rowe); tyrosine aminotransferase (TAT) (G. Schultz); phenobarbital-inducible cytochrome P450 (M. Adesnik); and androsterone-uridine diphosphoglucuronyl transferase (UDPGT) (J. Roy Chowdhury). Nonrecombinant plasmid pBR322 and 28-S rDNA $(0.5$ $\mu \mathrm{g} / \mathrm{slot})$ were used as negative and positive controls, respectively. After baking at $80^{\circ} \mathrm{C}$ for $4 \mathrm{~h}$, the filters were prehybridized for $4 \mathrm{~h}$ in a solution containing $50 \%$ deionized formamide, $2 \times$ Denhardt's solution, $5 \times$ SET buffer $(1 \times$ SET buffer is $30 \mathrm{mM}$ Tris- $\mathrm{HCl}, 150 \mathrm{mM} \mathrm{NaCl}$, pH 8.0, and $1 \mathrm{mM}$ EDTA), $0.1 \%$ SDS, and $400 \mu \mathrm{g} / \mathrm{ml}$ carrier wheat germ tRNA. Subsequently, filters were hybridized at $42^{\circ} \mathrm{C}$ for $36 \mathrm{~h}$ in fresh hybridization solution, containing the radioactively labeled RNA and $200 \mu \mathrm{g} / \mathrm{ml}$ carrier wheat germ RNA. After hybridization to total labeled RNA, filters were washed twice at room temperature in $2 \times$ standard saline citrate (SSC), $0.1 \%$ SDS, for $30 \mathrm{~min}$; then once at $65^{\circ} \mathrm{C}$ in $1 \times \mathrm{SSC}, 0.1 \% \mathrm{SDS}$, for $30 \mathrm{~min}$; and finally twice at $65^{\circ} \mathrm{C}$ in $0.1 \times$ SSC, $0.1 \%$ SDS, for $30 \mathrm{~min}$ and exposed to autoradiography at $-80^{\circ} \mathrm{C}$ on Kodak XAR-5 film, using intensifier screens (Lightening Plus; DuPont Co., Wilmington, DE). For each experiment, at least three differently timed autoradiographic exposures were obtained. The relative signal intensities of appropriate autoradiograms, in which the exposure was in the linear range, as well as integrations of tracings, were obtained with a laser densitometer (Ultroscan; LKB Instruments Inc., Gaithersburg, MD).

RNA blot analysis. Specific mRNA steady-state levels were determined in total RNA extracted from SDR and NAR liver under control and experimental conditions, using the acid guanidium thiocyanatephenol-chloroform extraction as described by Chomczynski and Sac- chi (23). $10 \mu \mathrm{g}$ of total RNA were heat denatured for $5 \mathrm{~min}$ at $65^{\circ} \mathrm{C}$ in buffer containing $50 \%$ formamide, $2.4 \mathrm{M}$ formaldehyde, and $1 \times$ MOPS (10× MOPS is $0.2 \mathrm{M}$ 3-N(morpholino)propanesulfonic acid [MOPS], $50 \mathrm{mM}$ sodium acetate, $10 \mathrm{mM} \mathrm{Na}{ }_{2}$ EDTA) and applied to a $1.2 \%$ agarose/formaldehyde gel made up in $1 \times$ MOPS. The gel was run in $1 \times$ MOPS, pH 7.4, at $80 \mathrm{~V}$ for $4 \mathrm{~h}$. After electrophoresis, the RNA was transferred to filters (Hybond N; Amersham, Searle Corp.) by capillary action and fixed to the filter by ultraviolet (UV) crosslinking. The blots were prehybridized for $4 \mathrm{~h}$ at $42^{\circ} \mathrm{C}$ in $50 \%$ formamide, $5 \times \mathrm{SSC}$, $50 \mathrm{mM}$ sodium phosphate, $\mathrm{pH} 6.5,1 \times$ Denhardt's solution, and 100 $\mu \mathrm{g} / \mathrm{ml}$ denatured salmon sperm DNA. Hybridizations were performed in the same solutions with $2-3 \times 10^{6} \mathrm{cpm} / \mathrm{ml}$ of probe for $20 \mathrm{~h}$ at $42^{\circ} \mathrm{C}$. The DNA probes were labeled using a multiprimer labeling kit (Amersham, Searle Corp.), according to the manufacturer's directions and [ $\left.{ }^{32} \mathrm{P}\right] \mathrm{dCTP}$ (sp act 3,000 Ci/mmol), to obtain a sp act of 4.0-6.0 $\times 10^{8}$ $\mathrm{cpm} / \mu \mathrm{g}$ DNA. After hybridization, filters were washed essentially as described above for the nuclear "run on" transcription assay. After washing, filters were exposed to autoradiography at $-80^{\circ} \mathrm{C}$ on Kodak XAR-5 film, using intensifier screens (Lightening Plus; DuPont Co.). Quantitation of results was obtained by densitometry scanning of autoradiograms as noted.

$R N A$ slot-blot. For some mRNA quantitation experiments, total RNA was applied directly to a nitrocellulose filter using a slot-blot hybridization apparatus (Schleicher \& Schuell Inc.). $10 \mu \mathrm{g}$ of total RNA was heat denatured at $65^{\circ} \mathrm{C}$ for $10 \mathrm{~min}$ in a solution containing $20 \mathrm{X}$ SSC and $37 \%$ formaldehyde $(1: 1, \mathrm{vol} / \mathrm{vol})$ and applied to each slot. Experimental points were determined in duplicate. Hybridization and washing procedures, as well as quantitation of results, were as for Northern blot analysis. The advantage of the slot-blot method for RNA quantitation is that all specimens are applied to a geometrically fixed area on the filter and this makes it easier to compare hybridization signal produced by one sample versus another.

Biochemical and physiological measurements. Albumin levels were measured in serum samples obtained from rats before and after albumin infusion by standard biochemical procedures (24). Serum samples from analbuminemic rats were also analyzed by rocket immunoelectrophoresis. Dextran was determined with anthrone by the method of Roe (25) and $\gamma$-globulins by serum protein electrophoresis (26). Serum COP was kindly measured by Dr. George Kaysen, University of California, Davis, using a strain gauge microoncometer (Statham Instruments, Oxnard, CA).

Statistical analyses. Biochemical, physiological, and densitometric data are expressed as means \pm SD. Significant differences between mean values of saline control and macromolecule infused rats were evaluated using the $t$ test.

\section{Results}

Table I summarizes the results of albumin, dextran, or $\gamma$-globulin measurements in serum samples obtained from SDR before and 2 or $24 \mathrm{~h}$ after infusion of various macromolecules. After albumin infusion in SDR, serum albumin concentrations, as evaluated in three different experiments, were increased to $5.7 \pm 0.3 \mathrm{~g} / \mathrm{dl}$ at $2 \mathrm{~h}$ and $4.1 \pm 0.3 \mathrm{~g} / \mathrm{dl}$ at $24 \mathrm{~h}$ after injection (basal level $3.3 \pm 0.3 \mathrm{~g} / \mathrm{dl}$ ). In NAR, the serum level of albumin was $1.6 \pm 0.2 \mathrm{~g} / \mathrm{dl}$ at $24 \mathrm{~h}$ after infusion (basal level $2.5 \mathrm{mg} / \mathrm{dL}$, as determined by rocket immunoelectrophoresis). Parallel increases were also noted in serum oncotic pressure at 2 and $24 \mathrm{~h}$ after albumin infusion in both SDR and NAR (Table II).

Since changes in gene expression occurring within the first $12 \mathrm{~h}$ after intravenous infusion of macromolecules or induction of anesthesia could be attributed to stress-induced acute phase effects, all studies were performed at 20-24 h after infusing various agents. Fig. 1 shows a representative "run on" transcription experiment in which the relative transcription rate of 10 genes was analyzed in NAR under control and experimental 
Table I. Serum Concentrations Obtained by Intravenous Infusion of Albumin, Dextran, or $\gamma$-Globulin in Normal Rats

\begin{tabular}{lccc}
\hline & \multicolumn{3}{c}{ Concentrations } \\
\cline { 2 - 4 } $\begin{array}{c}\text { Substance } \\
\text { infused and } \\
\text { measured }\end{array}$ & Before infusion & & \multicolumn{2}{c}{ After infusion } \\
\cline { 2 - 4 } \cline { 3 - 4 } & $0 \mathrm{~h}$ & $\mathrm{~g} / 100 \mathrm{ml}$ plasma & $24 \mathrm{~h}$ \\
\hline Albumin & $3.3 \pm 0.3$ & $5.7 \pm 0.3^{*}$ & $4.1 \pm 0.3^{\ddagger}$ \\
Dextran & 0 & $3.2 \pm 0.3^{*}$ & $1.4 \pm 0.2^{*}$ \\
$\gamma$-Globulin & $0.4 \pm 0.3$ & $1.8 \pm 0.2^{*}$ & $0.9 \pm 0.3^{\ddagger}$ \\
\hline
\end{tabular}

Values are means \pm SD of results obtained in three separate experiments. Analysis of changes in serum proteins or dextran after intravenous infusion showed statistically significant results at both 2 and $24 \mathrm{~h}$ postinfusion. ${ }^{*} P<0.001 ;^{\ddagger} P<0.05$ ( $t$ test).

conditions. The transcription rate of the albumin gene was twofold higher in NAR than in normal SDR. The intravenous infusion of albumin in NAR decreased the albumin transcription rate significantly at $24 \mathrm{~h}$ after infusion (average decrease $\sim 60 \%$ ). Transcription of the apo E gene, which was higher in NAR than in SDR under basal conditions, was also substantially reduced by albumin infusion in NAR. However, after albumin infusion, there was no significant change in the relative transcription rate of several other genes, including those coding for liver-specific functions (TAT and fibrinogen), liverenriched functions (apo B, apo A-I, and Tf), or general cellular functions ( $\beta$-actin, $\alpha_{2}$-coll, or $\alpha$-tubulin).

To determine whether albumin infusion could change the basal level of constitutive albumin gene expression in normal rats, SDR were infused intravenously with albumin. Fig. 2 shows an evident drop in albumin gene transcription, detectable $24 \mathrm{~h}$ after infusion of albumin. Quantitation of results obtained from three different experiments indicated a 50-60\% decrease in the albumin transcription rate after albumin infusion in normal SDR (Table III). As shown in Fig. 2, the transcriptional activity of apo $\mathrm{E}$ is also lower in albumin-infused than in control animals (infused with saline). No significant change in the relative transcription rate of albumin was detected after administering $<1.5 \mathrm{mg} / \mathrm{g}$ body wt of serum albumin to either NAR or SDR (data not shown).

To test the specificity of the inhibitory effect of albumin infusion on albumin gene transcription, SDR rats were infused

Table II. Serum Colloid Osmotic Pressure in Sprague-Dawley and Nagase Analbuminemic Rats before and after Albumin Infusion

\begin{tabular}{lccr}
\hline & \multirow{2}{c}{$\begin{array}{c}\text { Before } \\
\text { infusion }\end{array}$} & $2 \mathrm{~h}$ & $24 \mathrm{~h}$ \\
\cline { 3 - 4 } & & $\mathrm{mmHg}$ & \\
& & $27.0 \pm 2.2$ & $23.7 \pm 1.5$ \\
SDR & $18.2 \pm 2.1$ & $24.3 \pm 2.4$ & $21.6 \pm 0.6$
\end{tabular}

Values are means $\pm S D$ of results obtained in three separate experiments. Analysis of changes in serum colloid osmotic pressure after intravenous infusion of serum albumin showed statistically significant results at both 2 and $24 \mathrm{~h}$ postinfusion $(P<0.001, t$ test $)$.

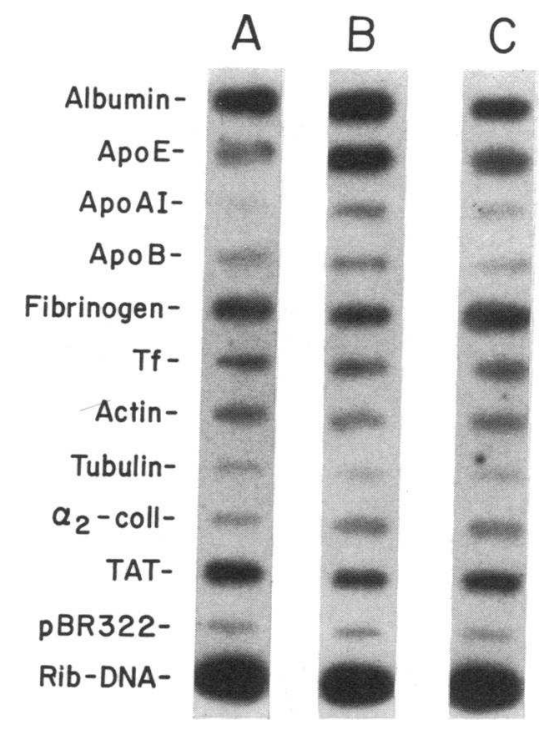

Figure 1. Relative transcription rate of liver genes in NAR vs. SDR: effect of intravenous infusion of albumin. Nascent RNA chains in isolated liver nuclei obtained from normal SDR infused with saline $(A)$, NAR infused with saline $(B)$, or NAR infused with albumin $(C)$ were elongated in the presence of $\left[{ }^{32} \mathrm{P}\right] U T \mathrm{TP}$. $20 \times 10^{6} \mathrm{cpm}$ of labeled RNA was then hybridized to cloned specific cDNA sequences (noted on the left) applied as slots to nitrocellulose filters. See Methods for additional experimental details. The autoradiogram of a "run on" transcription assay, representative of results obtained in four separate experiments, is shown.

intravenously with an equal amount of nonprotein (dextran) or other protein ( $\gamma$-globulins) macromolecules. Fig. 3 shows that infusion of either dextran or $\gamma$-globulins significantly reduced albumin gene transcription. Upon dextran and $\gamma$-globulins infusion, transcription of many other genes, including those coding for liver-specific, liver-enriched, and general cellular functions (Fig. 3), was not affected. The same results were obtained after infusing NAR with these macromolecules (data not shown).

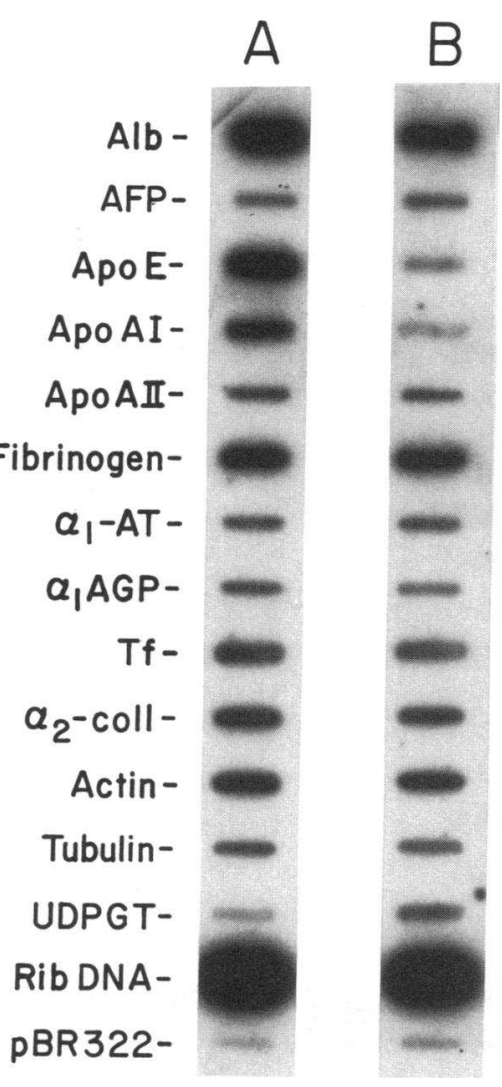

Figure 2. Effect of albumin infusion on the relative transcription rate of liver genes in SDR. Nascent RNA chains in liver nuclei isolated from SDR infused with saline $(A)$ or albumin $(B)$ were elongated in the presence of $\left[{ }^{32}\right.$ P]UTP. $20 \times 10^{6} \mathrm{cpm}$ of labeled RNA was then hybridized to cloned specific cDNA sequences (noted on the left) applied as slots to nitrocellulose filters. Autoradiogram of a "run on" transcription assay, representative of results obtained in three separate experiments, is shown. 
Table III. Effects of Albumin or Dextran Infusion on the Relative Transcription Rate and mRNA Steady-State Level of Albumin and $\beta$-actin Genes

\begin{tabular}{|c|c|c|c|c|c|c|}
\hline \multirow[b]{3}{*}{ Infusion } & \multicolumn{4}{|c|}{ Relative gene transcription rate } & & \\
\hline & \multicolumn{2}{|c|}{ Albumin } & \multicolumn{2}{|c|}{$\beta$-Actin } & \multicolumn{2}{|c|}{ mRNA steady-state level } \\
\hline & NAR & SDR & NAR & SDR & Albumin & $\beta$-Actin \\
\hline Saline & $1.00 \pm 0.05$ & $1.00 \pm 0.04$ & $1.00 \pm 0.05$ & $1.00 \pm 0.02$ & $1.00 \pm 0.09$ & $1.00 \pm 0.02$ \\
\hline Albumin & $0.38 \pm 0.08^{*}$ & $0.53 \pm 0.10^{\ddagger}$ & $0.90 \pm 0.05$ & $0.98 \pm 0.03$ & $0.50 \pm 0.05^{*}$ & $0.97 \pm 0.02$ \\
\hline Dextran & $0.42 \pm 0.08^{*}$ & $0.42 \pm 0.11^{*}$ & $1.05 \pm 0.04$ & $0.98 \pm 0.02$ & $0.47 \pm 0.03^{*}$ & $0.95 \pm 0.05$ \\
\hline
\end{tabular}

Densitometric tracings of autoradiograms were obtained from "run-on" transcription assays or RNA slot blot analyses. The mean value of the area under the curve for in vitro elongated mRNA chains or accumulated mRNAs from saline-infused animals was set at 1.00 in arbitrary units. Values are means \pm SD of results obtained in three separate experiments (three animals per group). mRNA steady-state level was measured in SDR only. Statistical analyses of results from macromolecule vs. saline-infused rats: ${ }^{*} P<0.001 ;{ }^{\ddagger} P<0.05$ ( $t$ test).

To test whether the steady-state level of albumin mRNA changed in concert with the transcription rate of the gene upon macromolecule infusion, accumulation of albumin transcripts was analyzed under control and experimental conditions. Representative examples of such experiments are shown in Fig. 4. The infusion of serum albumin or dextran decreased by $50-$ $60 \%$ the steady-state level of albumin mRNA (Fig. 4 and Table II), comparable to the change observed in the relative transcription rate of the albumin gene (Table II). However, the relative transcription rate and mRNA steady-state level for a housekeeping gene (i.e., $\beta$-actin, see Table III and Fig. 4) and the mRNA levels for acute-phase-related genes (e.g., $\beta$-fibrinogen and $\alpha_{1}$-AGP; see Fig. 4) were unchanged after macromolecule infusion.

In regard to other genes analyzed in this study, the transcription of only apo E was consistently down-regulated by macromolecule infusion in either NAR or SDR. A $30-50 \%$ drop in transcription for $\beta$-fibrinogen or apo A-I was sometimes noted in individual animals but was not a consistent finding. As indicated above, the expression of other liver-speci-

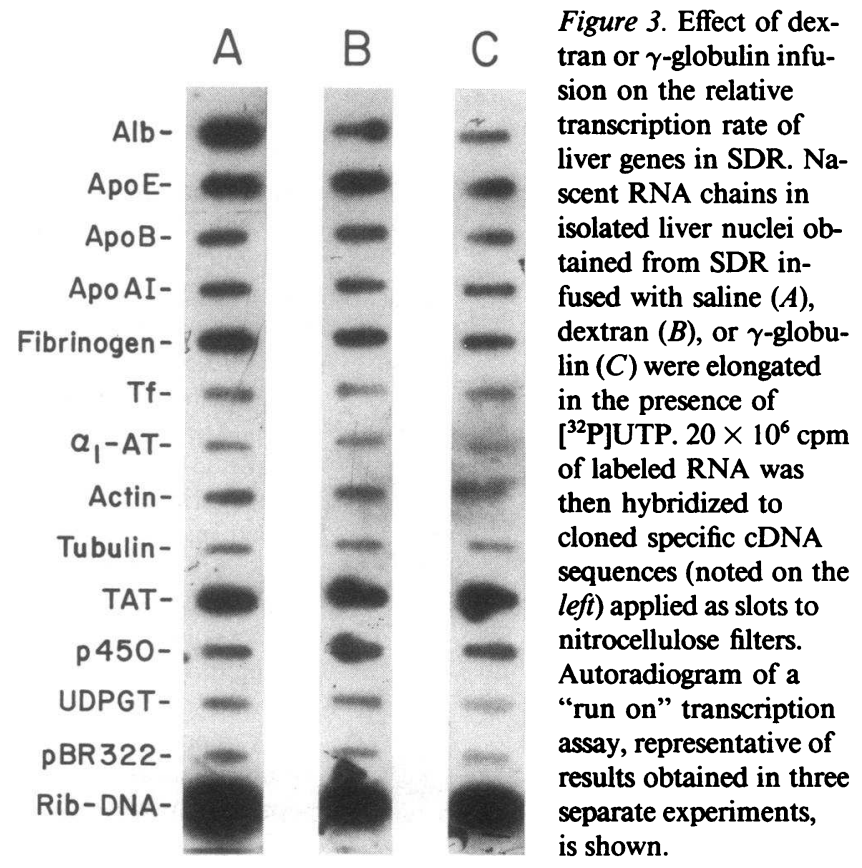

fic or liver-enriched genes (TAT, cytochrome P-450, UDPGT, apo A-II and B), acute-phase genes ( $\alpha_{1}$-AGP, $\alpha_{1}$-AT), and housekeeping genes ( $\alpha$-tubulin, $\alpha_{2}$-coll, and $\beta$-actin) was not affected under the same experimental conditions.

\section{Discussion}

The main goal of this study was to use a molecular approach to test the hypothesis that changes in serum colloids can modulate expression of the albumin gene in vivo. Rats genetically deficient in circulating albumin and with a reduced serum COP (NAR) showed a twofold increase in the transcription rate of the albumin gene compared with normal SDR. This increase was consistently down-regulated by raising the serum albumin to $1.6 \mathrm{~g} / \mathrm{dl}$ and serum COP to normal. An appreciable decrease in transcriptional activity of the albumin gene was also found in normal SDR subjected to intravenous infusion of albumin. This down-regulation appears to control the steady-state level of albumin mRNA in the liver. A similar inhibitory effect on albumin gene expression was also observed after infusion of other protein or nonprotein macromolecules, such as $\gamma$-globulins and dextran, respectively.

The finding that apo E expression was also significantly influenced by albumin or macromolecule infusion is not surprising, since our previous studies have shown that the pattern of apo E gene expression in the liver mimics that of albumin during several physiological or pathophysiological states, in-

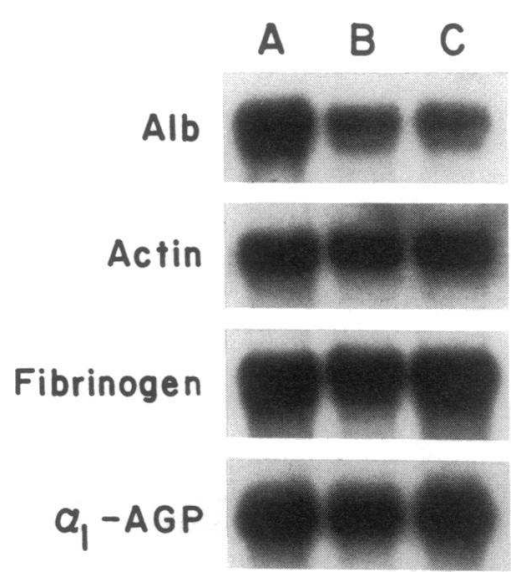

Figure 4. Effect of albumin infusion on the steady-state level of specific mRNAs. Total cellular RNA (10 $\mu \mathrm{g})$ isolated from the liver of SDR infused with saline $(A)$, albumin $(B)$, or dextran $(C)$ was electrophoresed in a $1.2 \%$ formaldehyde/agarose gel and blotted to nylon filter membranes. Autoradiograms of filters hybridized with various cDNA probes, as noted on the left, are shown. 
cluding normal development, liver regeneration, and hepatic fibrosis $(21,27)$. Such a behavior of these two transcriptionally regulated genes may indicate a coordinate regulation at the molecular level, possibly due to structural homologies in the enhancer/promoter regions responsive to specific nuclear transcriptional factors. Recently, a well-known transcriptional activator (LF B-1/HNF-1), which interacts in a sequence-specific manner with the promoter of some liver-specific or -enriched genes, including $\beta$-fibrinogen (28), has been found also to bind to a specific cis-element in the albumin promoter (element B) (29). The element $B$ and its cognate factor are known to play a dominant role in directing liver-specific expression of the albumin gene (30). Thus, inhibition of specific expression by infused macromolecules may occur with other polymerase IItranscribed genes in addition to albumin. A well-documented circumstance in which albumin synthesis is subjected to negative regulatory control is during the acute-phase response (31). As to the experimental manipulations used in the present study, the intravenous injection of high molecular weight macromolecules may induce a "stress" response. However, this effect is transient; and our observation that neither the transcriptional activity nor the steady-state mRNA level of two representative acute phase reactants in rats (i.e., fibrinogen and $\alpha_{1}$-AGP) were increased at $24 \mathrm{~h}$ after macromolecule infusion rules out this possibility. In fact, although the major mediators of the acute-phase response, such as cytokines and glucocorticoids (32), inhibit albumin synthesis, such a phenomenon is usually accompanied by a concomitant increase in the expression of "positive" acute phase genes, including fibrinogen and $\alpha_{1}$-AGP (33), which was not observed. An additional control for acute phase effects was the infusion of saline into control animals and comparison to untreated animals after $24 \mathrm{~h}$, with essentially no change in the relative transcription rate for albumin or other genes included in this study.

Our data suggest transcriptional down-regulation as the molecular basis for inhibition of albumin synthesis by albumin, dextran, or $\gamma$-globulin infusion $(11-13,16-18)$. The nature of the signal responsible for this apparent feedback regulation is at present unknown. An attractive possibility, supported by our data, is that the specific modulatory signal is mediated by changes in the COP that result from fluctuations in the serum or plasma level of albumin or other colloids. As originally proposed by Rothschild et al. (16), such a colloid-mediated regulatory mechanism is presumably localized within the liver, perhaps in the interstitial space (i.e., space of Disse) (34). However, in this region of the liver, the effective COP is thought to be low (35), and the actual concentrations of colloids in Disse's space may not reflect their concentration in the circulation. In fact, in addition to the barrier exerted by liver sinusoids to the passage of very large macromolecules (36), the bulk of interstitial fluid is occupied by a protein-polysaccharide matrix, which causes an uneven distribution of proteins; and part of the fluid in the hepatic interstitial space is itself excluded to proteins (37-39).

It is also known that infusion of high molecular weight compounds displaces albumin from the intravascular space toward the interstitial spaces (34). Thus, infusion of other proteins, such as $\gamma$-globulin, could induce an altered distribution of circulating albumin, thereby exerting an oncotic effect in the liver interstitial space higher than that predicted on the basis of their mass or serum concentration. All these factors could result in a detectable effect on hepatic gene activity, even when there are only limited changes in the actual serum concentration of infused macromolecules or COP after infusion.

Aside from the COP, other factors may also be involved in feedback regulation of albumin synthesis. Vasopressin, a vasoactive nonapeptide produced by the posterior pituitary, has been found capable of decreasing albumin mRNA levels in primary cultures of rat hepatocytes (40). It appears unlikely, however, that such an osmotically regulated substance might be released upon infusion of macromolecules, which are known to account for $<0.5 \%$ of total plasma osmolarity (41). In contrast, a change in plasma volume with subsequent release of other peptides, such as the atrial natriuretic peptides (atriopeptins), is more likely to occur after albumin or dextran infusion (42). Atriopeptins act in an integrative manner on a number of target organs to modulate cardiovascular function and fluid balance. Recently, a modulatory activity of atriopeptins on vasopressin release from the hypophysis has been proposed (43). The interplay of these vasoactive peptides on a systemic basis may, therefore, influence the metabolic function of specific organs, as recently suggested for volume regulatory responses modulating hepatic ammonia metabolism (44). However, since an inhibitory effect on albumin synthesis by colloids has also been described in ex vivo systems (16-18), this suggests that "systemic" factors, such as vasopressin or atriopeptins, are not required.

Whatever the nature of the factor(s) that triggers feedback modulation of albumin expression, the physiological target of this modulatory phenomenon seems to be transcription of the albumin gene. Transient expression experiments and in vitro transcription assays of rodent albumin promoters have shown that the DNA sequences necessary and sufficient for hepatocyte-specific transcription are located within 150-170 base pairs immediately upstream of the albumin cap site $(45,46)$. Yet, other far upstream sequences, the functions or binding activities of which have not yet been identified, may be involved in developmental or environmental control of albumin gene expression (47-49). Studies are now in progress to identify specific 5 ' upstream sequences in the albumin gene that confer the regulatory response to this novel feedback regulatory mechanism.

\section{Acknowledgments}

The authors thank Dr. George Kaysen for serum colloid osmotic pressure measurements and Drs. A. Karmen and V. V. Murthy for measurements of serum proteins.

This research was supported in part by National Institutes of Health (NIH) grants DK-17609 and P30-DK-41296, as well as funds from the Marion Bessin Liver Research Center. Dr. Antonello Pietrangelo is the recipient of a North Atlantic Treaty Organization Advanced Fellowship Award and a NIH John E. Fogarty International Fellowship.

\section{References}

1. Peters, T., Jr., and C. B. Anfinsen. 1950. Net production of serum albumin by liver slices. J. Biochem. 86:805-813.

2. Miller, L. L., C. G. Bly, M. L. Watson, and W. F. Bale. 1951. The dominant role of the liver in plasma protein synthesis: a direct study of the isolated perfused rat liver with the aid of lysine-epsilon C14. J. Exp. Med. 94:431-453.

3. Liang, T. J., and G. Grieninger. 1981. Direct effect of insulin on the synthesis of specific proteins: biphasic response of hepatocytes cultured in serum- and hormone-free medium. Proc. Natl. Acad. Sci. USA. 78:6972-6976.

4. Matsui, H., H. Yazawa, N. Suzuki, and T. Hosoya. 1986. Effects of glucocorticoid and cycloheximide on the activity and amount of RNA polymerase I in nuclei of rat liver. Biochem. J. 235:699-705. 
5. Shafritz, D. A., S. H. Yap, and R. K. Strair. 1979. Regulation of albumin synthesis in rat liver. Mol. Biol. Rep. 5:71-78.

6. Oratz, M., M. A. Rothschild, S. S. Schreiber, A. Burks, J. Mongelli, and B. Matarese. 1983. The role of the urea cycle and polyamines in albumin synthesis. Hepatology. 3:567-571.

7. Oratz, M., M. A. Rothschild, and S. S. Schreiber. 1988. Serum albumin. Hepatology. 8:385-401.

8. Biorneboe, M. 1946. Studies on the serum proteins in hepatitis. I. The relation between serum albumin and serum globulin. Acta Med. Scand. 123:393401.

9. Biorneboe, M., and M. Schwartz. 1959. Investigations concerning the changes in serum proteins during immunization: the cause of hypoalbuminemia with high globulin values. J. Exp. Med. 110:259-270.

10. Waldenstrom, J. 1952. Abnormal proteins in myeloma. Adv. Intern. Med. 5:398-405.

11. Rothschild, M. A., M. Oratz, J. Mongelli, and S. S. Schreiber. 1965. Albumin metabolism in rabbits during gamma globulin infusions. J. Lab. Clin. Med. 66:733-740.

12. Rothschild, M. A., M. Oratz, E. Wimer, and S. S. Schreiber. 1961. Studies on albumin synthesis. The effects of dextran and cortisone on albumin metabolism in rabbits studied with albumin- $\mathrm{I}^{131}$. J. Clin. Invest. 40:545-554.

13. Tracht, M. E., L. Tallal, and D. G. Tracht. 1967. Intrinsic hepatic control of plasma albumin concentration. Life Sci. 6:2621-2628.

14. Andersen, S. B., and N. Rossing. 1967. Metabolism of albumin and $\gamma \mathrm{G}-$ globulin during albumin infusions and during plasmapheresis. Scand. J. Clin. Lab. Invest. 20:183-184.

15. Katz, J., G. Bonorris, S. Okuyama, and A. L. Sellers. 1967. Albumin synthesis in perfused liver of normal and nephrotic rats. Am. J. Physiol. 212:1255-1260.

16. Rothschild, M. A., M. Oratz, J. Mongelli, and S. S. Schreiber. 1969. Effect of albumin concentration on albumin synthesis in the perfused liver. Am. J. Physiol. 216:1127-1130.

17. Dich, J., S. E. Hansen, and H. I. D. Thieden. 1973. Effect of albumin concentration and colloid osmotic pressure on albumin synthesis in the perfused rat liver. Acta Physiol. Scand. 89:352-358.

18. Huberman, A. 1973. The in vitro effect of colloid osmotic pressure on albumin biosynthesis in normal rat liver. Rev. Invest. Clin. 25:321-330.

19. Nagase, S., K. Shimamune, and S. Shumiya. 1979. Albumin-deficient rat mutant. Science (Wash. DC). 209:590-591.

20. Joles, J. A., N. Willekes-Koolschijn, B. Braam, W. Kortlandt, H. A. Koomans, and E. J. Dorhout Mees. 1989. Colloid osmotic pressure in young analbuminemic rats. Am. J. Physiol. 257:F23-F28.

21. Panduro, A., F. Shalaby, F. R. Weiner, L. Biempica, M. A. Zern, and D. A. Shafritz. 1986. Transcriptional regulation of liver-specific gene expression in rats treated with $\mathrm{CCl}_{4}$. Biochemistry. 25:1414-1420.

22. Clayton, D. E., and J. E. Darnell, Jr. 1983. Changes in liver-specific compared to common gene transcription during primary culture of mouse hepatocytes. Mol. Cell. Biol. 3:1552-1561.

23. Chomczynski, P., and N. Sacchi. 1987. Single-step method of RNA isolation by acid guanidinium thiocyanate-phenol-chloroform extraction. Anal. Biochem. 162:156-159.

24. Doumas, B. T., W. A. Waston, and H. G. Biggs. 1971. Allbumin standards and the measurement of serum albumin with bromocresol green. Clin. Chim. Acta. 31:87-96.

25. Roe, J. H. 1954. The determination of dextran in blood and urine with anthrone reagent. J. Biol. Chem. 208:889-896.

26. Alper, C. A. 1974. Plasma protein measurements as a diagnostic aid. $N$. Engl. J. Med. 291:287-290.

27. Panduro, A., F. Shalaby, and D. A. Shafritz. 1987. Changing patterns of transcriptional and post-transcriptional control of liver-specific gene expression during rat development. Genes Dev. 1:1172-1182.
28. Baumhueter, S., D. B. Mendel, P. B. Conley, C. J. Kuo, C. Turk M. K Graves, C. A. Edwards, G. Curtuois, and G. R. Crabtree. 1990. HNF-1 share three sequence motifs with the POU domain proteins and is identical to LF-B and APF. Genes Dev. 4:372-379.

29. Lichtsteiner, S., and U. Schibler. 1989. A glycosylated liver-specific transcription factor stimulates transcription of the albumin gene. Cell. 57:1179-1187.

30. Maire, P., J. Wuarin, and U. Schibler. 1989. The role of cis-acting elements in tissue-specific albumin gene expression. Science (Wash. DC). 244:343 346.

31. Baumann, H. 1989. Hepatic acute phase reaction in vivo and in vitro. In Vitro Cell. Dev. Biol. 25:115-126.

32. Castell, J. V., T. Andus, D. Kunz, and P. C. Heinrich. 1989. Interleukin-6 the major regulator of acute-phase protein synthesis in man and rat. Ann. NY Acad. Sci. 557:87-101.

33. Schreiber, G., A. Tsykin, A. R. Aldred, T. Thomas, W.-P. Fung, P. W. Dickson, T. Cole, H. Birch, F. A. De Jong, and J. Milland. 1988. The acute phase response in the rodent. Ann. NY Acad. Sci. 557:61-85.

34. Rothschild, M. A., M. Oratz, C. D. Evans, and S. S. Schreiber. 1966. Role of hepatic interstitial albumin in regulating albumin synthesis. Am. J. Physiol. 210:57-62.

35. Brauer, R. W. 1963. Liver circulation and function. Physiol. Rev. 43:115213.

36. Mayerson, H. S., C. G. Wolfram, H. H. Shinley, Jr., and K. Wasserman. 1960. Regional differences in capillary permeability. Am. J. Physiol. 198:155160.

37. Trowell, O. A. 1946. The experimental production of water vacuolation of the liver. J. Physiol. (Lond.). 105:268-297.

38. Ogston, A. G., and C. F. Phelps. 1961. The partition of solutes between buffer solutions and solutions containing hyaluronic acid. Biochem. J. 78:827833.

39. Laurent, T. C. 1963. The interaction between polysaccharides and other macromolecules. 5. The solubility of proteins in the presence of dextran. Bio chem. J. 89:253-257.

40. Chojkier, M., D. A. Brenner, and H. L. Leffert. 1989. Vasopressin inhibits type-I collagen and albumin gene expression in primary cultures of adult rat hepatocytes. J. Biol. Chem. 264:9583-9591.

41. Weisburg, H. F. 1978. Osmotic pressure of the serum proteins. Ann. Clin. Lab. Sci. 8:155-164.

42. Goetz, K. L. 1988. Physiology and pathophysiology of atrial peptides. Am. J. Physiol. 254:E1-E15.

43. Januszewicz, P., J. Gutkowska, A. De Lean, G. Thibault, R. Garcia, J. Genest, and M. Cantin. 1985. Synthetic atrial natriuretic factor induces release (possibly receptor mediated) of vasopressin from rat posterior pituitary. Proc. Soc. Exp. Biol. Med. 178:321-325.

44. Haussinger, D., F. Lang, K. Bauers, and W. Gerok. 1990. Control of hepatic nitrogen metabolism and glutathione release by cell volume regulatory mechanisms. Eur. J. Biochem. 193:891-898.

45. Heard, J.-M., P. Herbomel, M.-O. Ott, A. Mottura-Rollier, M. Weiss, and M. Yaniv. 1987. Determinants of rat albumin promoter tissue specificity analyzed by an improved transient expression system. Mol. Cell. Biol. 7:2425-2434. 46. Gorski, K., M. Carneiro, and U. Schibler. 1986. Tissue-specific in vitro transcription from the mouse albumin promoter. Cell. 47:767-776.

47. Pinkert, C. A., D. M. Ornitz, R. L. Brinster, and R. D. Palmiter. 1987. An albumin enhancer located $10 \mathrm{~Kb}$ upstream functions along with its promoter to direct efficient, liver specific expression in transgenic mice. Genes Dev. 1:268276.

48. Herbst, R. S., E. M. Boczko, J. E. Darnell, and L. E. Babiss. 1990. The mouse albumin enhancer contains a negative regulatory element that interacts with a novel DNA-binding protein. Mol. Cell. Biol. 10:3896-3905.

49. Liu, J. K., C. M. DiPersio, and K. S. Zaret. 1991. Extracellular signals that regulate liver transcription factors during hepatic differentiation in vitro. $\mathrm{Mol}$. Cell. Biol. 11:773-784. 